\title{
Breeding biology and long-term population dynamics of the Pied Flycatcher Ficedula hypoleuca in Skibotn, Northern Norway
}

\author{
Antero Järvinen \\ Kilpisjärvi Biological Station, University of Helsinki, 99490 Kilpisjärvi, Finland; antero.jarvinen@helsinki.fi
}

\begin{abstract}
The breeding biology and population dynamics of the Pied Flycatcher Ficedula hypoleuca in pine, mixed and deciduous forests in Skibotn, Northern Norway $\left(69^{\circ} 20^{\prime} \mathrm{N}, 20^{\circ} 20^{\prime} \mathrm{E}\right)$, was studied during 33 years (1987-2019; in total 1775 completed first clutches). It was a period during which summer temperatures remained relatively stable, but late spring (May) temperatures tended to become warmer. The number of breeding pairs declined over the study period but varied less than in populations living in more harsh subalpine environments. In spite of the northern location, females started to lay eggs in a relatively late phenological phase of the environment and in relatively warm weather. The date of birch leafing and the date of egg-laying advanced during the study period, and they correlated with each other. Mean clutch size was 6.4 eggs, and mean number of fledglings/nest 4.6. Date of egg-laying was earlier and clutch size larger in deciduous forests than in pine and mixed forests, but this did not translate into better fledgling productivity. The main causes of nesting failure were predation by small mustelids and starvation in warm and dry summers. However, in the long run the population seemed to be able to maintain itself without immigration, i.e., act as a source population. The possibility that during warm climate periods of the past, breeding biology and population dynamics of Pied Flycatchers over large geographical areas might have resembled those in Skibotn is discussed.
\end{abstract}

Keywords: Pied Flycatcher, Northern Norway, breeding biology, population dynamics, long-term study

\section{INTRODUCTION}

The present long-term population study of the Pied Flycatcher in Skibotn, Northern Norway, was initially intended to last for only three years. I had previously (Järvinen 1983, 1989) studied Pied Flycatchers in a subalpine mountain birch forest in nearby Kilpisjärvi (Northern Finland, $69^{\circ} 03^{\prime} \mathrm{N}, 20^{\circ} 50^{\prime} \mathrm{E}, 475-600 \mathrm{~m}$ a.s.l.) and wanted to know whether there were any differences in the breeding biology of the species between these adjacent (straight line distance $35 \mathrm{~km}$ ) but environmentally very different habitats (Järvinen 1993a). However, the first results from this Pied Flycatcher population breeding in relict pine forests (for Holocene climate history of the area, see Lilleøren et al. 2012) and other forests in Skibotn Valley were so interesting (Järvinen 1993a) that I decided to continue the work for a much longer period.

The results of the first three years (1987-89) suggested that compared to other northern areas Skibotn is a flycatcher's "paradise". Therefore, it was expected that a considerably extended time-series would confirm some of the earlier results as well as giving new insights into the factors that affect long-term population dynamics. An additional motivating factor was the fact that long-term bird population studies are rare in northern and/or peripheral areas where human population and the number of ornithologists/birders are low. Thus, my results may be helpful when we try to understand how and why northern nature varies and changes over time.

The purpose of the present study is to present facts about a Pied Flycatcher population at the northern limit of the species' breeding range using a long time-series (33 years). In northern and/or peripheral Scandinavia, there are few other long-term studies of hole-nesting birds whose results make it possible to see if there are repeatable patterns in reproductive traits and strategies (for Northern Finland, see Järvinen 1983; for Northern Sweden, Nyholm 2011; for Central Norway, Thingstad 1997).

\section{MATERIALS AND METHODS}

Skibotn Valley (about $69^{\circ} 20^{\prime} \mathrm{N}, 20^{\circ} 20^{\prime} \mathrm{E}$ ) is known for its dry climate with frequent clear skies, perhaps the place with the most sunshine hours in Norway, and the calcareous pine forests, with rare orchids. The study area (about $2 \mathrm{~km}^{2}$ ) was a relatively productive pine, mixed (birch, alder, aspen and pine), and deciduous woodland (Figure 1). The commercial Finnish nestboxes used were made of durable impregnated plywood with a $32 \mathrm{~mm}$ entrance hole (bottom area 11x12 cm). The nest-box area was established in early April in 1987. Initially, there were 100 nest-boxes (entrance hole about $1.5 \mathrm{~m}$ above the ground), but in spring 1988 one of them disappeared and another in spring 


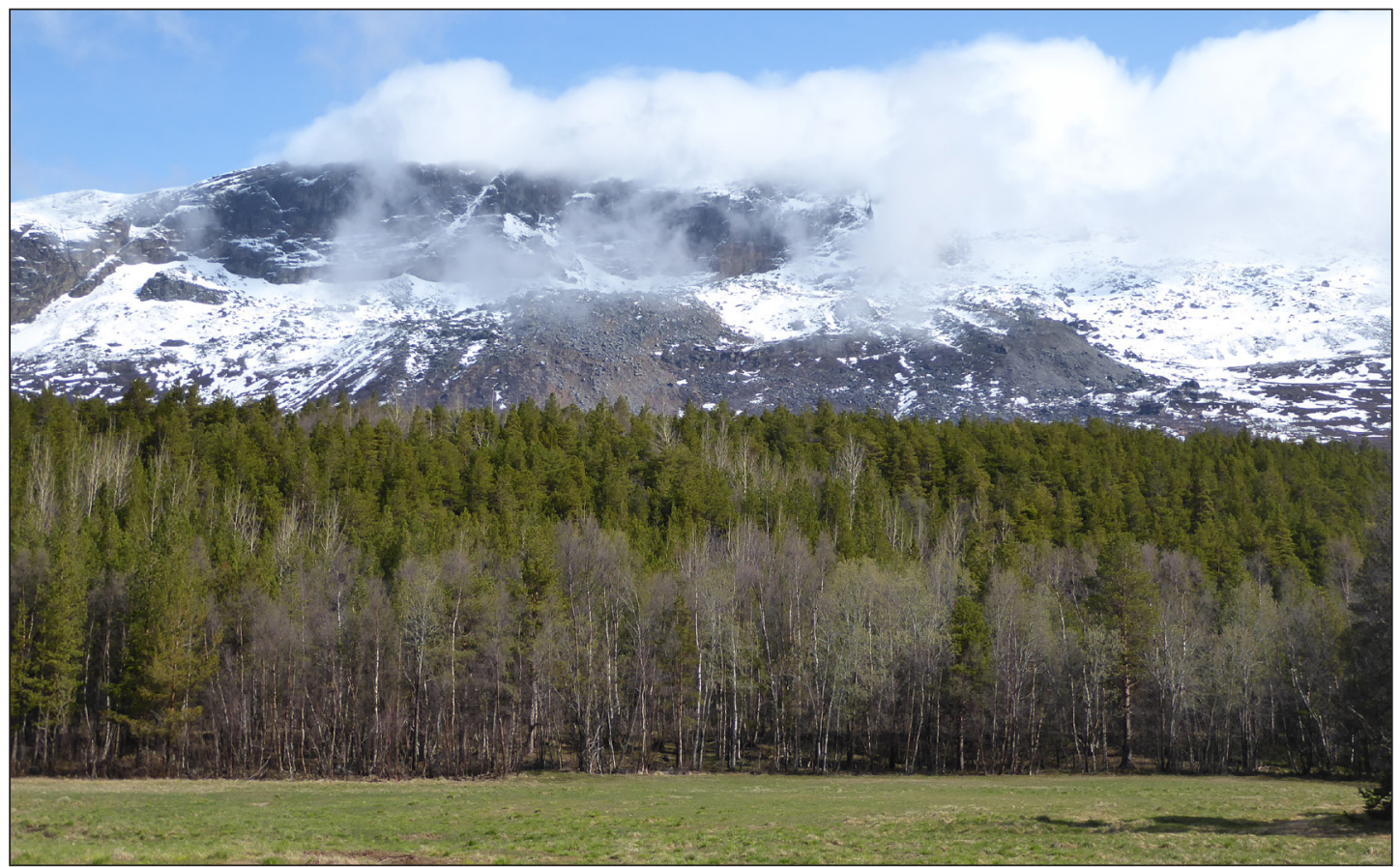

Figure 1. Scots pine and mixed forests of the study area in Skibotn, 23 May 2015. In the background Mount Ádjet, 1408 m a.s.1. Photo: Antero Järvinen.

1990. Both boxes were situated close to a path and were not replaced. Thus, the number of boxes was 98 in the subsequent years (1990-2019). The boxes were in mixed $(\mathrm{n}=51)$, pine $(\mathrm{n}=33)$ and deciduous forests $(\mathrm{n}=16)$ along a small river (Nedre Haskielva) and around Skibotn Field Station (University of Tromsø). The altitude of the boxes was 80-180 $\mathrm{m}$ a.s.1., the mean being $135 \mathrm{~m}$ a.s.l.

The Pied Flycatcher winters mainly in tropical West Africa. It has belonged to the breeding avifauna of Northern Norway for over 100 years (Haftorn 1971). According to my own observations since 1973, the species was a rare breeder in the Skibotn area before 1987. There are between 200000 and 1000000 breeding pairs in Norway (Bakken et al. 2006). The first birds arrive back to Norway in late April and leave in August-September (Bakken et al. 2006). In addition to Pied Flycatchers, every year also 2-20 Great Tits (Parus major) nested in the boxes and once (1991) the Pied Flycatcher and the Redstart (Phoenicurus phoenicurus) nested in the same box, the females incubating their own eggs side by side (Järvinen 1993b). No other Redstarts or other species nested in the boxes. Thus, the percentage of occupied nest-boxes varied from 32 (2019) to 87 (1998), the mean percentage being 64\%.

Nest-boxes were checked every 5-7 days throughout the breeding season. This allowed an accurate determination of the date of laying of the first egg (Pied Flycatcher lays one egg a day), clutch size and breeding success. Only genuine first clutches were included. Few replacement clutches were laid after nesting failure (predation) during the egg-laying period. I have no data on polygyny or the number of males that possibly remained unmated. Hatching success $(\%)$ equalled $100 \times$ no. of hatchlings/no. of eggs laid, fledging success (\%) equalled $100 \mathrm{x}$ no. of fledglings/no. of hatchlings and nesting success (\%) equalled $100 \mathrm{x}$ no. of fledglings/no. of eggs laid. Old nests were removed at the end of the breeding season. A nest was considered predated if it was demolished, i.e., eggs were broken and/or remains (legs, wings, etc.) of nestlings were found inside the box. Small mustelids (least weasel Mustela nivalis and stoat M. erminea) tend to turn over the whole nest. Woodpeckers did not predate nests. I have no data on the possible predation of adults by, for instance, raptors.

Temperature data came from Skibotn Observation Station (Norwegian Meteorological Institute) situated about five $\mathrm{km}$ north of the study area (20 $\mathrm{m}$ a.s.1.). The date of birch leafing, i.e., the date when petioles became visible in over $50 \%$ of birches (estimated by AJ every year) was used as an index of the developmental stage of the vegetation at the time when flycatchers were about to lay eggs. In 1987-90 females were trapped and ringed with Norwegian rings, and recaptured the following years. Site-tenacity of females was low (5\%), even lower than in Kilpisjärvi at the same time (11\%; Järvinen 1993a). Thus, they were too few to be included in the analysis of population dynamics. Females ringed in Skibotn were never controlled in nearby Kilpisjärvi, or vice versa. Some nestlings were ringed but none of them was later recorded as breeders in the boxes. During the study period over 1000 nestlings were ringed in nearby Kilpisjärvi but none of them was 


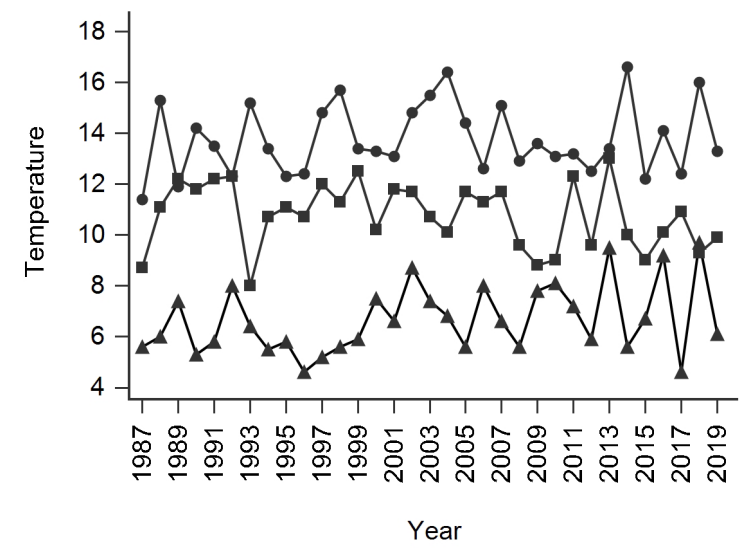

Figure 2. Mean air temperature $\left({ }^{\circ} \mathrm{C}\right)$ in May (triangles), June (squares) and July (dots) in Skibotn in 1987-2019.

controlled in Skibotn.

For statistical analyses, the SYSTAT package was used. Coefficients of variation (CV) were tested with Forkman's (2009) method. To test whether there was a point at which a change occurred in values of time-series, the change-point test with allowance for ties was used (Siegel \& Castellan 1988). If possible, robust nonparametric tests (Spearman correlation coefficient, $r_{s}$, Kendall's concordance coefficient and Kruskal-Wallis test, corrected for ties) were preferred to parametric ones. To make comparisons easier with earlier studies, the "calendar effect" of clutch size (v. Haartman 1967) was estimated with ordinary linear regression analysis. Annual heterogeneity of these slopes was tested with analysis of covariance (ANCOVA). Influence of predation rate (after logit transformation of proportions) and mean temperatures in May, June and July on the mean number of fledglings/ nest was tested using multiple regression analysis. Significance tests are two-tailed.

\section{RESULTS}

Mean monthly temperatures during the summer seasons when the Pied Flycatcher bred in Skibotn are given in Figure 2. Compared to some other northern areas such as Kilpisjärvi, temperatures were relatively warm in Skibotn (Table 1). As is usually the case in almost every environmental parameter studied in the North, there was great annual variation in monthly temperatures, but no trends. There was, however, some indication that May temperature had become warmer $\left(r_{\mathrm{S}}=0.32, \mathrm{n}=33, \mathrm{p}=0.07\right)$. Moreover, May, June and July temperatures did not vary in synchrony (Kendall's concordance coefficient $=0.34, p>0.40$ ).

The mean number of breeding pairs (at least one egg produced) varied between 26 and 79, the mean being 56 pairs (Table 1). Population size was relatively stable in the first part of the study period but showed

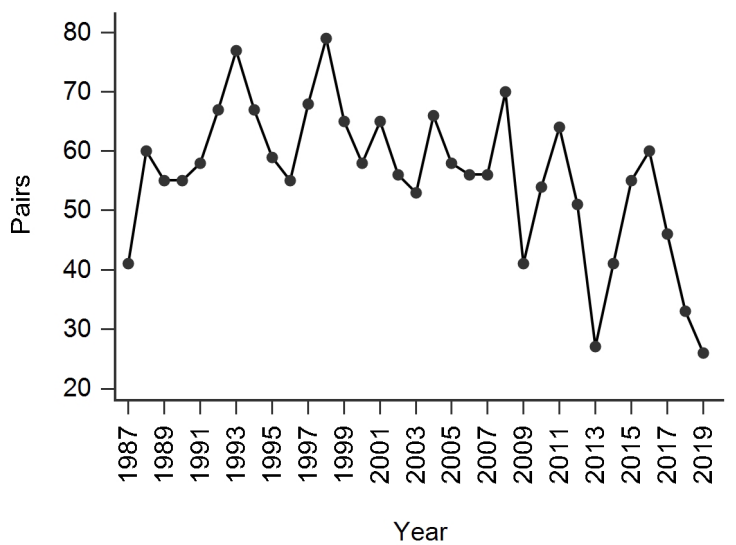

Figure 3. Number of breeding Pied Flycatcher nests (at least one egg laid/nest) in Skibotn in 1987-2019.

great variation and a declining trend in the latter part of the study period (Figure 3). Change-point test indicated that a change occurred after year $2008(\mathrm{n}=33, \mathrm{p}=$ $0.002)$. The overall trend was negative $\left(r_{\mathrm{s}}=-0.44, \mathrm{n}=\right.$ $33, \mathrm{p}<0.01)$. There was a significant autocorrelation in the number of breeding pairs/year with a lag of one year $(r=0.49, n=32, p<0.05)$, i.e., population size in year $t$ seemed to depend on population size in year $t-1$. Population size was not significantly related to the number of fledglings produced in the previous summer $\left(\mathrm{r}_{\mathrm{S}}=0.30, \mathrm{n}=32, \mathrm{p}=0.10\right)$.

Annual variations in the mean date of birch leafing and the mean date of laying of the first egg in clutches are shown in Figure 4. Both traits varied a lot. In the first part of the study period there seemed to be a declining trend in both variables, but in the latter part these trends seemed to vanish. In birch leafing, change occurred after year 2001 (change-point test, $p=0.002$ ), in egg-laying after year $1998(\mathrm{p}=0.004)$. However, when both periods are considered together, the trends were significant $\left(\mathrm{r}_{\mathrm{S}}\right.$ for birch leafing $=-0.39, \mathrm{n}=33$, $\mathrm{p}=0.02, \mathrm{r}_{\mathrm{s}}$ for egg-laying $=-0.38, \mathrm{n}=33, \mathrm{p}=0.03$ ). Consequently, there was a close correlation between birch leafing and egg-laying $\left(\mathrm{r}_{\mathrm{s}}=0.64, \mathrm{n}=33, \mathrm{p}<\right.$ $0.001)$. Both variables also correlated with mean air temperature in May: $\mathrm{r}_{\mathrm{s}}=-0.86, \mathrm{n}=33, \mathrm{p}<0.001$ (birch leafing) and $r_{S}=-0.58, n=33, p<0.001$ (egg-laying).

A summary of average environmental and breeding variable values based on annual means ( $\mathrm{n}=33$ years) is given in Table 1. Annual data for the main study variables are in Appendix 1. There was great annual variation in the three basic reproductive parameters (viz. clutch size, no. of hatchlings/nest and no. of fledglings/nest) without trends (Figure 5; $r_{\mathrm{s}}=0.168, \mathrm{p}$ $=0.35, \mathrm{r}_{\mathrm{s}}=-0.140, \mathrm{p}=0.44$ and $\mathrm{r}_{\mathrm{s}}=-0.126, \mathrm{p}=0.48$, respectively). When breeding variable calculations were based on completed clutches (Figure 6; $n=1775$ ), the means were the same as in Table 1: clutch size 6.4 eggs $(\mathrm{SD}=0.83)$, number of hatchlings/nest 5.7 (1.71) and number of fledglings/nest 4.6 (2.4). When 
Table 1. Environmental and breeding variable values of the Pied Flycatcher population in Skibotn in 1987-2019. Calculated from annual means $(n=33)$.

\begin{tabular}{lllll}
\hline Variable & Mean & SD & Range & Median \\
\hline May air temperature, ${ }^{\circ} \mathrm{C}$ & 6.7 & 1.4 & $4.6-9.7$ & 6.4 \\
${\text { June air temperature, }{ }^{\circ} \mathrm{C}}^{\circ}$ & 10.8 & 1.3 & $8.0-13.0$ & 10.9 \\
July air temperature, ${ }^{\circ} \mathrm{C}$ & 13.8 & 1.4 & $11.4-16.6$ & 14.4 \\
Number of breeding pairs & 56 & 12 & $26-79$ & 56 \\
Date of birch leafing & 30 May & 5.9 & 20 May-9 June & 31 May \\
Date of laying of the first egg & 5 June & 3.3 & 31 May-12 June & 5 June \\
Clutch size & 6.4 & 0.2 & $5.9-7.0$ & 6.4 \\
Number of hatchlings/pair & 5.7 & 0.5 & $4.5-8.4$ & 5.8 \\
Number of fledglings/pair & 4.6 & 1.3 & $1.7-6.2$ & 5.0 \\
Hatching success, $\%$ & 89 & 6 & $72-97$ & 91 \\
Fledging success, $\%$ & 80 & 18 & $31-99$ & 89 \\
Nesting success, $\%$ & 72 & 19 & $26-96$ & 77 \\
\hline
\end{tabular}

Table 2. Breeding variable values of the Pied Flycatcher population in Skibotn in relation to forest type (pine, mixed and deciduous forest) in 1987-2019. Values calculated from completed clutches. Temperature $=$ mean temperature during a two-week period 9 days before and 4 days after the laying of the first egg in a clutch. * $=$ significant difference.

\begin{tabular}{llll}
\hline Variable & Pine & Mixed & Deciduous \\
\hline Temperature, ${ }^{\circ} \mathrm{C}$ & $9.8(\mathrm{SD}=1.86, \mathrm{n}=542)$ & 9.6 $(\mathrm{SD}=1.93, \mathrm{n}=937)$ & 9.5 $(\mathrm{SD}=1.81, \mathrm{n}=294)$ \\
*Date of egg laying $^{*}$ & 6 June $(\mathrm{SD}=5.5, \mathrm{n}=559)$ & 6 June $(\mathrm{SD}=5.7, \mathrm{n}=974)$ & 4 June $(\mathrm{SD}=6.1, \mathrm{n}=307)$ \\
*Clutch size $^{\text {Fledglings/pair }}$ & 6.26 $(\mathrm{SD}=0.85, \mathrm{n}=542)$ & $6.36(\mathrm{SD}=0.81, \mathrm{n}=937)$ & $6.65(\mathrm{SD}=0.79, \mathrm{n}=294)$ \\
Predation, \% & $4.72(\mathrm{SD}=2.23, \mathrm{n}=542)$ & $4.57(\mathrm{SD}=2.48, \mathrm{n}=937)$ & $4.55(\mathrm{SD}=2.49, \mathrm{n}=294)$ \\
\hline
\end{tabular}

only non-predated nests were considered the number of fledglings/nest rose to $4.9(\mathrm{SD}=2.2, \mathrm{n}=1680)$. On average, larger clutches produced more fledglings than smaller clutches $\left(\mathrm{r}_{\mathrm{s}}=0.43, \mathrm{n}=1768, \mathrm{p}<0.001\right)$.

On average, early clutches were larger than late ones, the decline or "calendar effect" being 0.07 eggs/ day (common slope; $\mathrm{n}=1775, \mathrm{p}<0.001)$. There were no annual differences in slopes (ANCOVA, $F=1.330$, $\mathrm{df}=32,1709 \mathrm{p}>0.10)$. Forest type seemed to affect egg-laying date and clutch size (Kruskal- Wallis tests, $\mathrm{H}=27.6$ and $39.7, \mathrm{df}=2, \mathrm{p}<0.001$ ), the differences being due to early laying dates and large clutches in deciduous forests (Dwass-Steel-Critchlow-Fligner multiple comparison tests, $\mathrm{p}<0.001)$. The other differences were clearly nonsignificant $(\mathrm{p}>0.25$; Table 2). Thus, larger clutches in deciduous forests did not produce more young/nest. The mean number of eggs/ year correlated with the mean number of fledglings/ year $\left(r_{\mathrm{s}}=0.46, \mathrm{n}=33, \mathrm{p}=0.007\right)$.

Relative annual variation (coefficient of variation, $\mathrm{CV}$ ) based on means was only $3 \%$ in clutch size, $9 \%$ in the number of hatchlings/nest and as high as $29 \%$ in the number of fledglings/nest, the two latter $\mathrm{CV}$ values being greater $(p<0.001)$ than the $C V$ value for clutch size. Annual clutch size variation was relatively modest in Skibotn (Figure 5), but due to large sample sizes (total $\mathrm{n}=1775$ ) it is highly significant (Kruskal-Wallis test, $\mathrm{H}=138.29, \mathrm{df}=32, \mathrm{p}<0.001)$.

Also the number of fledglings/nest was not significantly related to temperature in May, June or July $\left(\mathrm{n}=33 ; \mathrm{r}_{\mathrm{S}}=-0.04, \mathrm{p}=0.81, \mathrm{r}_{\mathrm{S}}=0.29, \mathrm{p}=0.10\right.$ and $r_{s}=0.12, p=0.51$, respectively). Losses due to predation of small mustelids varied annually (Figure 7) and they were distributed more or less randomly across the nest-box area. Of all nests, $17 \%$ did not produce a single nestling. In these unproductive nests $(n=293)$ the failure was caused by predation in $32 \%$ of the cases. Another important reason for breeding failure seemed to be starvation, i.e., food shortage of nestlings, during warm and dry summers, especially in pine forests. For instance, in 1988 hungry nestlings were crying for food and even old (10-12 days) ones died of starvation. However, exact numbers are not available because it was often hard to determine whether it was starvation or some other factor that killed nestlings in intact, non-predated, nests. According to multiple regression analysis, mean annual number of fledglings/nest depended only on predation rate $(t=4.58, \mathrm{df}=4,28, \mathrm{p}$ 


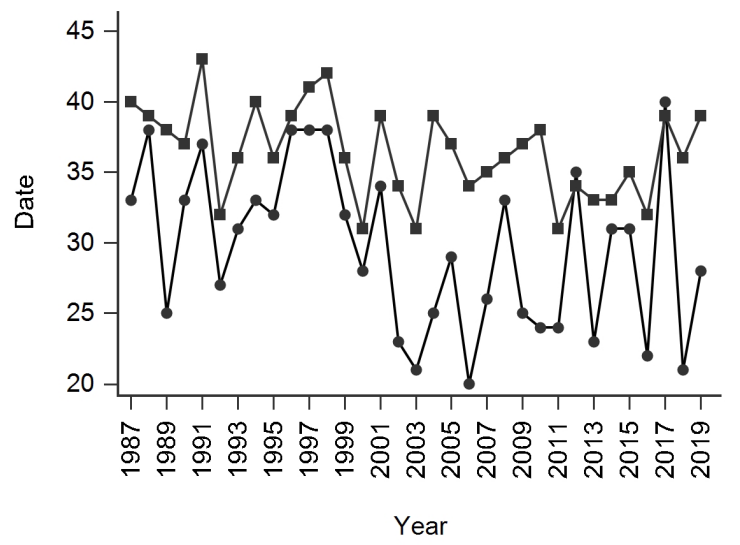

Figure 4. Date of birch leafing (dots) and date of laying of the first egg (squares) of Pied Flycatcher females in Skibotn in 1987-2019. Y-axis (date): $31=31$ May, $32=1$ June, $33=$ 2 June, etc..

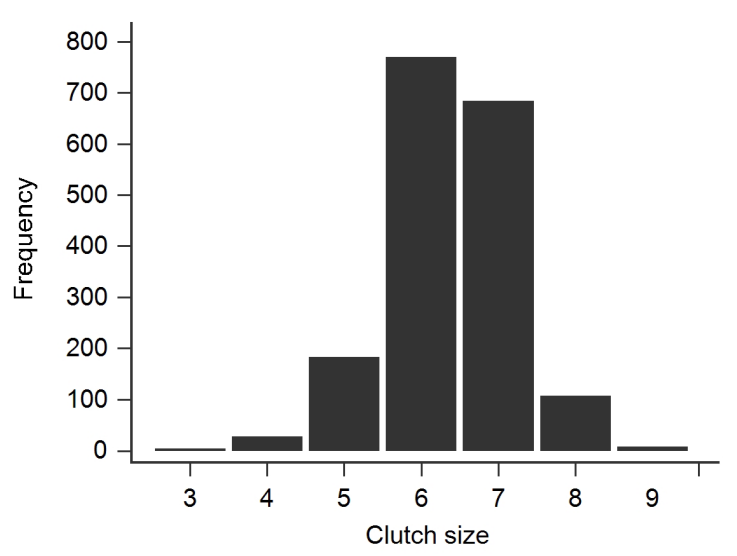

Figure 6. Clutch size distribution of the Pied Flycatcher in Skibotn in 1987-2019 (range 3-9 eggs, mean $=6.4, \mathrm{SD}=$ $0.83, \mathrm{n}=1775)$.

$<0.001$ ) and not on May, June and July temperatures (all $\mathrm{p}>0.10)$.

\section{DISCUSSION}

Especially in northern areas, years are not related: huge annual variation characterizes almost every environmental and biological variable studied (Remmert 1980, Järvinen 1983, 1989). The results of long-term ecological studies are important, because only they can uncover the natural range of variation in breeding parameters, thus providing the baseline and an early warning system that helps us to judge the relevance of variations and changes we see today.

In the present study, relatively few statistically significant trends were observed. Some of them, for instance the declining number of breeding Pied Flycatcher pairs (Figure 3), are probably real. Declining population trends have been observed also in Kilpisjärvi ( $69^{\circ} \mathrm{N}$; own obs.), Northern Sweden $\left(66^{\circ} \mathrm{N}\right)$

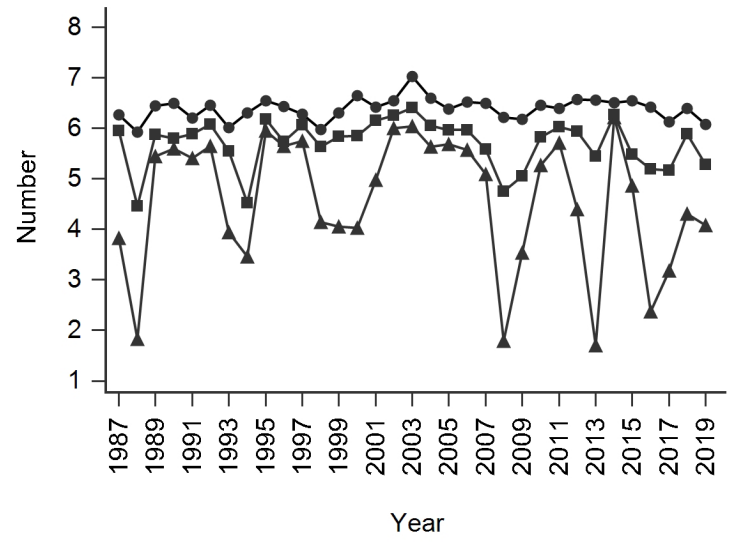

Figure 5. Annual mean clutch size (dots), mean number of hatchlings (squares) and mean number of fledglings (triangles) per nest in Skibotn in 1987-2019.

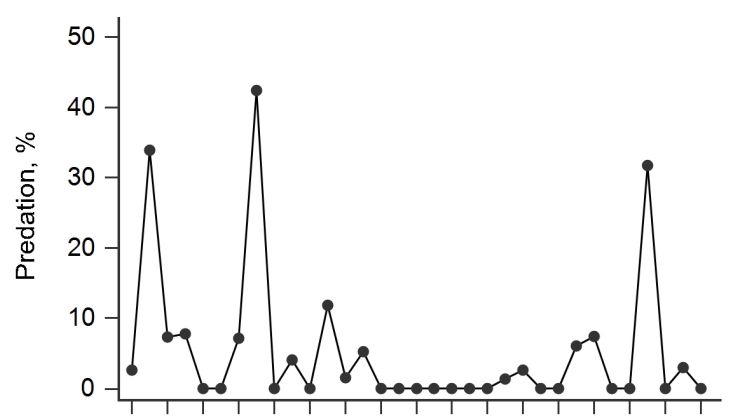

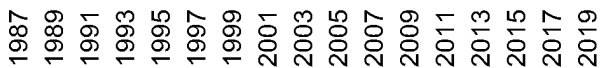

Year

Figure 7. Predation rate (\%) of Pied Flycatcher nests by small mustelids in Skibotn in 1987-2019.

and Central Norway ( $64^{\circ} \mathrm{N}$; Thingstad et al. 2006) since the 1970s. Autocorrelation analysis suggested that population size was positively associated with population size the previous year. Because local recruitment rate in Skibotn was relatively low, this effect could come about if breeding success in the north is correlated with breeding success in more southern regions. Perhaps good breeding success in southern and central parts of the Pied Flycatcher's distribution range translates to high population size the following summer also in the peripheral Skibotn population. However, in the local Skibotn population there was little statistical evidence to support the view that population size was related to the number of fledglings produced in the previous summer.

In short time-series, one or two extreme years may abolish a trend or even reverse it. Moreover, variation can be cyclical. For instance, small rodent numbers often vary in cycles (e.g. Järvinen 1990) that affect bird populations, too. Usually mustelids eat rodents but when rodents are scarce, they turn to alternative prey such as 
birds (Järvinen 1985, 1990, Nyholm 2011). If one starts a time-series study in a low "valley" and end it in a high "peak" of a natural cycle, one will automatically get a positive trend. Conversely, a negative trend would have been found if one had started the study at the peak of the same cycle instead. Likewise, in long timeseries even relatively small changes or differences can become statistically significant, even though they may be biologically irrelevant. For instance, annual clutch size variation was relatively modest in Skibotn (Figure 5), but due to large sample sizes highly significant.

As pointed out by Thingstad et al. (2006), weather conditions at the flycatcher's wintering areas in West Africa may be responsible for the decline in Pied Flycatcher population size, since temperature conditions in their study areas remained more or less stable. In Skibotn, too, summer temperatures varied much but without clear trends (Figure 2). There was some indication that May temperature had become warmer, but even this trend was not significant. In Kilpisjärvi the situation has been similar: May temperatures have warmed but June and July temperatures have remained more or less stable since the late 1960s (Järvinen 1989 $\&$ unpubl. data). Likewise, there was no trend in the number of fledglings produced/year but, again, large annual variation (Figure 5). Moreover, the number of fledglings/nest was not significantly related to temperature unlike in harsh environmental conditions of Kilpisjärvi (Järvinen 1983, 1989).

In Western Europe, Pied Flycatchers have advanced their breeding time (Both et al. 2004), but Thingstad et al. (2006; see also Barrett 2002) observed little evidence of any trends in the onset of spring in northern Scandinavia. In Skibotn birch leafing and egg-laying tended to become earlier in first part of the study period, but this trend seemed to level off in the end of 1990s or in the beginning of 2000s (Figure 4).

This study confirms Slagsvold's (1976) observation that in climatically favourable (warm) areas birds tend to start breeding in an earlier phenological phase of the environment than those in climatically unfavourable (cold) areas. Even though my study area in Skibotn lies only $35 \mathrm{~km}$ north of my study area in Kilpisjärvi, climate is clearly warmer in Skibotn due to lower altitude and the proximity of the Arctic Ocean (Lyngenfjord), which is ice free even in winter (Järvinen 1993a). In Skibotn, mean air temperature in May was $4.4^{\circ} \mathrm{C}$ warmer than in Kilpisjärvi, the corresponding figures for June and July being $3.1^{\circ} \mathrm{C}$ and $2.2^{\circ} \mathrm{C}$. The date of birch leafing was 17 days earlier and the date of egg-laying 6 days earlier in Skibotn than in Kilpisjärvi. Thus, in Skibotn birches started to leaf about a week before Pied Flycatcher females laid their first egg (Table 1) when the mean daily air temperature was quite warm. At the same time, in Kilpisjärvi birches started to leaf in mid-June and about a week after the flycatchers had laid their first egg in cold weather (own obs.). Also Pied Flycatchers in subalpine birch forests of Ammarnäs started to breed in cold weather (Nyholm 2011).

The "calendar effect" of clutch size, i.e., decline of clutch size by $0.07 \mathrm{eggs} /$ day with the progress of the breeding season, was of the same order of magnitude as in the above-mentioned Swedish and Norwegian studies (about 0.07). In migratory birds, the best time for reproduction is often at the beginning of the breeding season (Crick et al. 1993). Date of egglaying seemed to be earliest and clutch size largest in deciduous forests (Table 2). Usually such differences are related to higher productivity of deciduous forests (Lundberg \& Alatalo 1992, Cramp 1993) but in Skibotn higher forest productivity, if present, did not seem to manifest in higher productivity of young (Table 2). In the whole material, productivity of fledglings/nest was better in larger than in smaller clutches, i.e., the resources females invested in larger clutches paid off.

In Skibotn, the most important reasons for breeding failures were nest predation by small mustelids (Figure 7) and starvation. High predation pressure was observed in Swedish Lapland too (Nyholm 2011). Predation pressure varied from year to year. Three years clearly stood out: 1988 (34\%), 1994 (42\%) and 2016 (32\%). I do not have data on small rodent numbers in Skibotn and, therefore, cannot say how breeding success was related to local small rodent density. However, since small rodent populations vary in synchrony in nearby areas, it is suggestive that in Kilpisjärvi catch index in June was low during the above-mentioned three years (H. Henttonen, pers. comm.). Since I do not have data on nestling weight, it is impossible to separate starvation due to lack of food from an alternative cause of nestling mortality, i.e., adult predation.

Physical factors, such as cold summer temperatures, did not have significant effect on breeding success unlike in more peripheral habitats in Scandinavia (Järvinen 1983, Thingstad et al. 2006). Annual mean nesting success did not correlate between Skibotn and Kilpisjärvi $\left(r_{s}=0.096, n=33, p=0.59\right)$, because the reasons (predation and starvation due to drought versus exposure to inclement weather) for poor nesting success vary regionally and annually. In subalpine forests in Norway and Sweden, the mean number of eggs/year correlated with the number of fledglings/ year (Thingstad et al. 2006). In spite of greatly varying losses due to predation and starvation, this was the case also in Skibotn.

Birds can usually invest only a limited amount of resources to reproduction in harsh environments (Järvinen 1986). Clutch size (6.4) and the number of fledglings produced per pair (4.6) were clearly higher in Skibotn than in nearby Kilpisjärvi (Järvinen 1983) and in Ammarnäs, Northern Sweden (Nyholm 2011). When predated nests were excluded, on average 4.9 young fledged/nest. These facts indicate that even though Skibotn lies further north than Kilpisjärvi 
and Ammarnäs, local breeding conditions are quite favourable for the Pied Flycatcher. For self-maintenance of a northern Pied Flycatcher population, at least 4.4 fledglings should be produced per completed clutch (Järvinen 1983). Thus, although annual variation was great (Figure 5), on average Skibotn seems to be a source area (sensu Murphy 2001) whereas subalpine Kilpisjärvi and Ammarnäs seem to be sink areas that cannot maintain their populations without immigration. That Skibotn appears to be a more favourable area for flycatcher reproduction than Kilpisjärvi is indicated also by the fact that the annual variation in the number of breeding pairs was relatively low in Skibotn compared to Kilpisjärvi (own obs., CV $22 \%$ vs. $48 \%$; F $=4.07$, df $=1,31 \mathrm{p}<0.001)$.

Compared to other long-term studies in northern Scandinavia, the results of the present study have shown that reproductive traits and strategies of the Pied Flycatcher vary even between nearby areas. Therefore, repeatable patterns in population parameters may be hard to find. In peripheral areas, the struggle for existence against the physical world is the chief concern of organisms. Although Skibotn lies at the northern edge of the Pied Flycatcher's breeding range, environmental conditions are relatively favourable for the species there. In peripheral areas, birds are generally sensitive to the slightest fluctuations of climate and weather. Because they exist at the margin of their distribution area, even a slight warming/cooling could be beneficial/harmful. Thus, warming or cooling may cause great changes in the factors that limit peripheral populations. If the effects of physical factors diminish, the effects of biotic factors (intra- and interspecific competition and predation) may increase and play a greater role in the periphery than they do today.

In the future, breeding strategies in climatically very harsh areas (e.g. Kilpisjärvi and Ammarnäs) may begin to resemble those of Skibotn, if physical conditions ameliorate. For instance, females of these sink populations may be able to invest in larger clutches and bigger eggs, thereby increasing their productivity and fitness (Järvinen \& Väisänen 1984, Järvinen 1994, Järvinen 1996). During the Holocene climate optimum about 5000-7000 years ago, temperature was warmer than today and pine forests had replaced most subalpine mountain birch forests currently dominating northern Scandinavia (Lilleøren et al. 2012, Łacka et al. 2019). At that time, also subalpine Pied Flycatcher populations were probably self-supporting source populations.

Acknowledgements. I am grateful to Karl-Birger Strann for arranging permission for me to do research work in Skibotn. Until the collapse of the Soviet Union (1991), Skibotn Valley was a militarily sensitive area where, for instance, photographing was restricted. My study area situated one kilometre north of Brennfjell Military Camp. In June 1986, my students and I were arrested while watching birds in the area ("Veien sperret, filmene tatt"; see Kven language newspaper Ruijan Kaiku, 29.1.2018). The camp was closed soon after the collapse. Kilpisjärvi Biological Station provided logistic support. Leslie Hyde, Juha Merilä, Tore Slagsvold and Kari Vepsäläinen suggested improvements on an earlier version of the manuscript.

\section{REFERENCES}

Bakken, V., Runde, O. \& Tjørve, E. 2006. Norsk ringmerkingsatlas (Norwegian bird ringing atlas), Vol. 2. Stavanger Museum, Stavanger.

Barrett, R. T. 2002. The phenology of spring bird migration to north Norway. Bird Study 49: 270-277.

Both, C., Artemiev, A., Cowie, R., Dekhuijzen, A., Eeva, T., Enemar, A., Gustafsson, L., Järvinen, A., Kerimov, A., Metcalfe, N., Nyholm, E., Potti, J., Ravussin, P.A., Sanz, J.J., Silverin, B., Slater, F., Sokolov, L., Török, J., Visser, M., Winkel, W., Wright, J. \& Zang, H. 2004. Large-scale geographical variation confirms that climate change causes birds to lay earlier. Proc. R. Soc. Lond. 271: 1657-1662.

Cramp, S. (ed.) 1993. Handbook of the birds of Europe, the Middle East and North Africa. The birds of the Western Palearctic. Volume VII. Flycatchers to Shrikes. Oxford University Press, Oxford.

Crick, H.Q.P., Gibbons, D.W. \& Magrath, R.D. 1993. Seasonal changes in clutch size in British birds. J. Anim. Ecol. 62: 263-273.

Forkman, J. 2009. Estimator and tests for common coefficients of variation in normal distributions. Communications in Statistics Theory and Methods 38: 233-251.

Haartman, L. von 1967. Clutch-size in the Pied Flycatcher. Proc. XIV Int. Orn. Congr., Oxford, pp. 155-164.

Haftorn, S. 1971. Norges fugler. Universitetsforlaget, Oslo. (In Norwegian)

Järvinen, A. 1985. Predation causing extended low densities in microtine cycles: implications from predation on holenesting passerines. Oikos 45: 157-158.

Järvinen, A. 1986. Clutch size of passerines in harsh environments. Oikos 46: 365-371.

Järvinen, A. 1989. Patterns and causes of long-term variation in reproductive traits of the Pied Flycatcher Ficedula hypoleuca in Finnish Lapland. Ornis Fennica 66: 24-31.

Järvinen, A. 1990. Changes in the abundance of birds in relation to small rodent density and predation rate in Finnish Lapland. Bird Study 37: 36-39.

Järvinen, A. 1993a. Spatial and temporal variation in reproductive traits of adjacent northern Pied Flycatcher Ficedula hypoleuca populations. Ornis Scandinavica 24: 33-40.

Järvinen, A. 1993b. Redstart and Pied Flycatcher nesting in the same box. Ornis Fennica 70: 117-118.

Järvinen, A. 1994. Global warming and egg size of birds. Ecography 17: 108-110. 
Järvinen, A. 1996. Correlation between egg size and clutch size in the Pied Flycatcher Ficedula hypoleuca in cold and warm summers. Ibis 137: 620-623.

Järvinen, A. \& Väisänen, R.A. 1984. Reproduction of Pied Flycatchers (Ficedula hypoleuca) in good and bad breeding seasons in a northern marginal area. Auk 101: 439-450.

Lilleøren, K.S., Etzelmüller, B., Schuler, T.V., Gisnås, K. \& Humlum, O. 2012. The relative age of mountain permafrost - estimation of Holocene permafrost limits in Norway. Global Planetary Change 92-93: 209-223.

Łacka, M., Cao, M., Rosell-Melé, A., Pawłowskaa, J., Kucharska, M., Forwicke, M. \& Zajączkowski, M. 2019. Postglacial paleoceanography of the western Barents Sea: Implications for alkenone-based sea surface temperatures and primary productivity. Quaternary Science Review 224: 1-14.

Lundberg, A. \& Alatalo, R.V. 1992. The Pied Flycatcher. T. \& A. D. Poyser, London.

Murphy, M.T. 2001. Source-sink dynamics of a declining Eastern Kingbird population and value of sink habitats. Conservation Biology 15: 737-748.

Nyholm, N.E.I. 2011. Dynamics and reproduction of a nest- box breeding population of the Pied Flycatcher Ficedula hypoleuca in a subalpine birch forest in Swedish Lapland during a period of 46 years. Ornis Svecica 21: 133-156.

Remmert, H. 1980. Arctic animal ecology. Springer-Verlag, Berlin.

Siegel, S. \& Castellan, N.J. Jr. 1988. Nonparametric statistics for the behavioral sciences, 2nd edn. McGraw Hill International, New York.

Slagsvold, T. 1976. Annual and geographical variation in the time of breeding of the Great Tit Parus major and the Pied Flycatcher Ficedula hypoleuca in relation to environmental phenology and spring temperature. Ornis Scandinavica 7: 127-145.

Thingstad, P.G. 1997. Annual and local reproductive variations of a Pied Flycatcher Ficedula hypoleuca population near a subalpine lake in Central Norway. Ornis Fennica 74: 39-49.

Thingstad, P.G., Nyholm, N.E.I. \& Fjeldheim, B. 2006. Pied Flycatcher Ficedula hypoleuca population dynamics in peripheral habitats in Scandinavia. Ardea 94: 211-223.

Received 28.01.2020. Accepted 06.06.2020 
Appendix 1. Annual data (1987-2019) for the main study variables.

\begin{tabular}{|c|c|c|c|c|c|}
\hline \multirow[t]{2}{*}{ Year } & & \multicolumn{3}{|c|}{ Variable } & \multirow[b]{2}{*}{ Fledglings } \\
\hline & & First egg & Clutch size & Hatchlings & \\
\hline \multirow[t]{4}{*}{1987} & Nests & 41 & 41 & 41 & 41 \\
\hline & Mean & 9 June & 6.26 & 5.95 & 3.82 \\
\hline & $\mathrm{SD}$ & 4.6 & 0.84 & 1.32 & 2.49 \\
\hline & Median & 8 June & 6 & 6 & 5 \\
\hline \multirow{4}{*}{1988} & Nests & 56 & 56 & 56 & 56 \\
\hline & Mean & 8 June & 5.93 & 4.24 & 1.73 \\
\hline & $\mathrm{SD}$ & 5.0 & 0.74 & 2.60 & 2.45 \\
\hline & Median & 7 June & 6 & 5 & 0 \\
\hline \multirow[t]{4}{*}{1989} & Nests & 55 & 55 & 55 & 55 \\
\hline & Mean & 7 June & 6.44 & 5.87 & 5.44 \\
\hline & $\mathrm{SD}$ & 5.1 & 0.88 & 1.71 & 1.87 \\
\hline & Median & 8 June & 6 & 6 & 6 \\
\hline \multirow[t]{4}{*}{1990} & Nests & 53 & 53 & 53 & 53 \\
\hline & Mean & 6 June & 6.49 & 5.80 & 5.59 \\
\hline & $\mathrm{SD}$ & 3.4 & 0.75 & 1.91 & 2.00 \\
\hline & Median & 5 June & 6 & 6 & 6 \\
\hline \multirow[t]{4}{*}{1991} & Nests & 55 & 55 & 55 & 55 \\
\hline & Mean & 12 June & 6.20 & 5.89 & 5.40 \\
\hline & $\mathrm{SD}$ & 1.8 & 0.85 & 1.13 & 1.21 \\
\hline & Median & 12 June & 6 & 6 & 6 \\
\hline \multirow[t]{4}{*}{1992} & Nests & 65 & 65 & 65 & 65 \\
\hline & Mean & 1 June & 6.45 & 6.08 & 5.65 \\
\hline & $\mathrm{SD}$ & 3.4 & 0.73 & 1.19 & 1.53 \\
\hline & Median & 1 June & 6 & 6 & 6 \\
\hline \multirow[t]{4}{*}{1993} & Nests & 71 & 71 & 71 & 71 \\
\hline & Mean & 5 June & 6.01 & 5.54 & 3.94 \\
\hline & $\mathrm{SD}$ & 5.9 & 1.05 & 1.38 & 2.26 \\
\hline & Median & 3 June & 6 & 6 & 4.5 \\
\hline \multirow[t]{4}{*}{1994} & Nests & 60 & 60 & 60 & 60 \\
\hline & Mean & 9 June & 6.30 & 4.53 & 3.46 \\
\hline & $\mathrm{SD}$ & 3.6 & 0.72 & 2.76 & 2.99 \\
\hline & Median & 9 June & 6 & 6 & 5 \\
\hline \multirow[t]{4}{*}{1995} & Nests & 57 & 57 & 57 & 57 \\
\hline & Mean & 5 June & 6.54 & 6.18 & 5.95 \\
\hline & $\mathrm{SD}$ & 3.3 & 0.83 & 1.07 & 1.37 \\
\hline & Median & 5 June & 7 & 6 & 6 \\
\hline \multirow[t]{4}{*}{1996} & Nests & 49 & 49 & 49 & 49 \\
\hline & Mean & 8 June & 6.43 & 5.73 & 5.65 \\
\hline & $\mathrm{SD}$ & 3.5 & 0.98 & 1.78 & 1.77 \\
\hline & Median & 7 June & 7 & 6 & 6 \\
\hline \multirow[t]{4}{*}{1997} & Nests & 65 & 65 & 65 & 65 \\
\hline & Mean & 10 June & 6.28 & 6.06 & 5.75 \\
\hline & $\mathrm{SD}$ & 3.9 & 0.74 & 0.79 & 1.21 \\
\hline & Median & 11 June & 6 & 6 & 6 \\
\hline
\end{tabular}


Appendix 1. Continued.

\begin{tabular}{|c|c|c|c|c|c|}
\hline \multirow[t]{2}{*}{ Year } & & \multicolumn{3}{|c|}{ Variable } & \multirow[b]{2}{*}{ Fledglings } \\
\hline & & First egg & Clutch size & Hatchlings & \\
\hline \multirow[t]{4}{*}{1998} & Nests & 76 & 76 & 76 & 76 \\
\hline & Mean & 11 June & 5.97 & 5.63 & 4.14 \\
\hline & $\mathrm{SD}$ & 4.5 & 0.77 & 1.20 & 2.12 \\
\hline & Median & 11 June & 6 & 6 & 5 \\
\hline \multirow[t]{4}{*}{1999} & Nests & 63 & 63 & 63 & 63 \\
\hline & Mean & 5 June & 6.30 & 5.84 & 4.05 \\
\hline & $\mathrm{SD}$ & 4.9 & 0.73 & 1.25 & 2.57 \\
\hline & Median & 3 June & 6 & 6 & 5 \\
\hline \multirow[t]{4}{*}{2000} & Nests & 58 & 58 & 58 & 58 \\
\hline & Mean & 31 May & 6.64 & 5.84 & 4.02 \\
\hline & $\mathrm{SD}$ & 5.5 & 1.02 & 1.99 & 2.71 \\
\hline & Median & 31 May & 7 & 6 & 5 \\
\hline \multirow[t]{4}{*}{2001} & Nests & 65 & 65 & 65 & 65 \\
\hline & Mean & 8 June & 6.42 & 6.15 & 4.97 \\
\hline & $\mathrm{SD}$ & 3.7 & 0.77 & 1.15 & 1.94 \\
\hline & Median & 8 June & 6 & 6 & 5 \\
\hline \multirow[t]{4}{*}{2002} & Nests & 56 & 56 & 56 & 56 \\
\hline & Mean & 3 June & 6.55 & 6.25 & 6.00 \\
\hline & $\mathrm{SD}$ & 5.1 & 0.89 & 1.30 & 1.31 \\
\hline & Median & 2 June & 7 & 6 & 6 \\
\hline \multirow[t]{4}{*}{2003} & Nests & 53 & 53 & 53 & 53 \\
\hline & Mean & 31 May & 7.02 & 6.40 & 6.04 \\
\hline & $\mathrm{SD}$ & 5.8 & 0.60 & 1.68 & 1.86 \\
\hline & Median & 1 June & 7 & 7 & 7 \\
\hline \multirow[t]{4}{*}{2004} & Nests & 62 & 62 & 62 & 62 \\
\hline & Mean & 8 June & 6.60 & 6.05 & 5.63 \\
\hline & $\mathrm{SD}$ & 4.7 & 0.64 & 1.44 & 1.79 \\
\hline & Median & 8 June & 7 & 6.5 & 6 \\
\hline \multirow[t]{4}{*}{2005} & Nests & 53 & 53 & 53 & 53 \\
\hline & Mean & 6 June & 6.38 & 5.96 & 5.68 \\
\hline & $\mathrm{SD}$ & 3.8 & 0.74 & 1.22 & 1.46 \\
\hline & Median & 6 June & 6 & 6 & 6 \\
\hline \multirow[t]{4}{*}{2006} & Nests & 54 & 54 & 54 & 54 \\
\hline & Mean & 3 June & 6.52 & 5.96 & 5.57 \\
\hline & $\mathrm{SD}$ & 5.8 & 1.00 & 1.67 & 1.77 \\
\hline & Median & 31 May & 7 & 6 & 6 \\
\hline \multirow[t]{4}{*}{2007} & Nests & 56 & 56 & 56 & 56 \\
\hline & Mean & 4 June & 6.45 & 5.55 & 5.05 \\
\hline & $\mathrm{SD}$ & 6.1 & 0.76 & 1.17 & 1.20 \\
\hline & Median & 3 June & 7 & 6 & 5 \\
\hline \multirow[t]{4}{*}{2008} & Nests & 69 & 69 & 69 & 69 \\
\hline & Mean & 5 June & 6.22 & 4.75 & 1.78 \\
\hline & $\mathrm{SD}$ & 3.6 & 0.70 & 2.39 & 2.16 \\
\hline & Median & 5 June & 6 & 6 & 0 \\
\hline
\end{tabular}


Appendix 1. Continued.

\begin{tabular}{|c|c|c|c|c|c|}
\hline \multirow[t]{2}{*}{ Year } & & \multicolumn{3}{|c|}{ Variable } & \multirow[b]{2}{*}{ Fledglings } \\
\hline & & First egg & Clutch size & Hatchlings & \\
\hline \multirow[t]{4}{*}{2009} & Nests & 38 & 38 & 38 & 38 \\
\hline & Mean & 7 June & 6.18 & 5.05 & 3.53 \\
\hline & $\mathrm{SD}$ & 5.9 & 0.69 & 2.04 & 2.48 \\
\hline & Median & 6 June & 6 & 6 & 4 \\
\hline \multirow[t]{4}{*}{2010} & Nests & 50 & 50 & 50 & 50 \\
\hline & Mean & 7 June & 6.46 & 5.94 & 5.37 \\
\hline & $\mathrm{SD}$ & 5.0 & 0.79 & 1.23 & 1.62 \\
\hline & Median & 8 June & 6 & 6 & 6 \\
\hline \multirow[t]{4}{*}{2011} & Nests & 62 & 62 & 62 & 62 \\
\hline & Mean & 31 May & 6.39 & 6.03 & 5.71 \\
\hline & $\mathrm{SD}$ & 6.4 & 0.88 & 1.24 & 1.58 \\
\hline & Median & 31 May & 6.5 & 6 & 6 \\
\hline \multirow[t]{4}{*}{2012} & Nests & 49 & 49 & 49 & 49 \\
\hline & Mean & 3 June & 6.57 & 5.94 & 4.39 \\
\hline & $\mathrm{SD}$ & 4.6 & 0.68 & 1.46 & 2.42 \\
\hline & Median & 3 June & 7 & 6 & 5 \\
\hline \multirow[t]{4}{*}{2013} & Nests & 27 & 27 & 27 & 27 \\
\hline & Mean & 2 June & 6.56 & 5.44 & 1.70 \\
\hline & $\mathrm{SD}$ & 6.0 & 0.75 & 2.08 & 2.64 \\
\hline & Median & 1 June & 7 & 6 & 0 \\
\hline \multirow[t]{4}{*}{2014} & Nests & 41 & 41 & 41 & 41 \\
\hline & Mean & 2 June & 6.51 & 6.27 & 6.22 \\
\hline & SD & 2.7 & 0.87 & 0.90 & 0.96 \\
\hline & Median & 2 June & 7 & 6 & 6 \\
\hline \multirow[t]{4}{*}{2015} & Nests & 56 & 56 & 56 & 56 \\
\hline & Mean & 4 June & 6.54 & 5.48 & 4.86 \\
\hline & $\mathrm{SD}$ & 5.2 & 0.71 & 2.11 & 2.32 \\
\hline & Median & 3 June & 7 & 6 & 6 \\
\hline \multirow[t]{4}{*}{2016} & Nests & 57 & 57 & 57 & 57 \\
\hline & Mean & 1 June & 6.42 & 5.19 & 2.37 \\
\hline & $\mathrm{SD}$ & 4.3 & 0.86 & 2.35 & 2.90 \\
\hline & Median & 1 June & 7 & 6 & 0 \\
\hline \multirow[t]{4}{*}{2017} & Nests & 45 & 45 & 45 & 45 \\
\hline & Mean & 8 June & 6.13 & 5.16 & 3.18 \\
\hline & $\mathrm{SD}$ & 3.9 & 0.81 & 2.04 & 2.53 \\
\hline & Median & 7 June & 6 & 6 & 4 \\
\hline \multirow[t]{4}{*}{2018} & Nests & 33 & 33 & 33 & 33 \\
\hline & Mean & 5 June & 6.39 & 5.88 & 4.30 \\
\hline & $\mathrm{SD}$ & 8.3 & 0.66 & 1.32 & 2.42 \\
\hline & Median & 5 June & 6 & 6 & 5 \\
\hline \multirow[t]{4}{*}{2019} & Nests & 25 & 25 & 25 & 25 \\
\hline & Mean & 8 June & 6.08 & 5.28 & 4.08 \\
\hline & $\mathrm{SD}$ & 6.6 & 1.0 & 1.95 & 2.27 \\
\hline & Median & 9 June & 6 & 6 & 5 \\
\hline
\end{tabular}

